J. Clin. Chem. Clin. Biochem.

Vol. 23, 1985, pp. 7-16

\title{
Short-Term and Long-Term Intra-Individual Variations and Critical Differences of Clinical Chemical Laboratory Parameters
}

\author{
By G. M. P. J. Costongs, P. C. W. Janson, B. M. Bas \\ Hospital "De Goddelijke Voorzienigheid", Sittard, The Netherlands
}

\section{J. Hermans}

Department of Statistics, University of Leiden, Leiden, The Netherlands

\section{J.W. J. van Wersch and P.J. Brombacher}

De Wever Hospital, Heerlen, The Netherlands

(Received March 21/August 2, 1984)

Summary: Twenty eight clinical chemical blood parameters were studied with respect to intra-individual variations. Both short term variations, within one day and during one week, and long term variations, during a six months period, were investigated in groups of 62,16 and 274 individuals. Moreover, critical differences were calculated from the total variations, i.e. physiological (personal) and analytical variations. The influences of external factors (sex, smoking, and oral contraceptives) were been studied.

It was concluded that the use of laboratory data in clinical diagnosis is considerably improved when intra-individual variations and critical differences are used.

Kurz- und langzeitige intraindividuelle Änderungen sowie kritische Differenzen klinisch-chemischer Kenngrößen

Zusammenfassung: Die intraindividuellen Änderungen von 28 klinisch-chemisch bestimmten Blutbestandteilen wurden untersucht. In Gruppen von 62, 16 und 274 Probanden wurden sowohl kurzzeitige Änderungen innerhalb eines Tages und während einer Woche als auch lạngzeitige Änderungen während eines halben Jahres verfolgt. Zusätzlich wurden aus den Gesamt-Änderungen, d.h. physiologischen (individuellen) und analytischen Variationen, kritische Differenzen berechnet. Weiterhin wurden äußere Einflüsse wie Geschlecht, Rauchen und Einnahme oraler Kontraceptiva untersucht.

Aus den Ergebnissen wird geschlossen, daß die Verwendung von Labordaten in der klinischen Diagnostik wesentlich verbessert wird, wenn intraindividuelle Variationen und kritische Differenzen benutzt werden.

\section{Introduction}

In medical practice physicians request clinical laboratory tests to assist in diagnosis, to suggest a type of treatment and to monitor the patient.

In general, support is sought for the confirmation of a preliminary diagnosis based on the patient's history and physical examination. The latter is often regarded as subject to personal interpretation whilst laboratory tests are considered to provide more objective information. As far as clinical chemistry is concerned, the information is obtained by chemical and physical procedures, estimating characteristic values.

Data obtained by laboratory investigation are destined for use in clinical decision making. As a matter of fact, for the diagnosis of a certain disease the data 
obtained from the diseased population are compared with those obtained from other comparable populations. The latter may preferably consist of healthy individuals although it is not always obvious how to define "healthy" in this context. Comparison with data from non-healthy individuals, but not having the investigated disease, also make sense.

The commonly used "reference range" is generally determined by analysis of a large number of blood samples taken from an apparently healthy group of individuals at a certain time (transverse reference values). Data obtained from blood samples of patients deviating from this range of "reference values" obtained from the healthy population, may indicate an unusual or even a pathological situation.

The investigated healthy reference population frequently consists of selected groups such as blood donors from the blood transfusion service, laboratory personal or medicine students. Evidently, this is not an ideal situation; several selection mechanisms may be present.

Comparison of patients' values with transverse reference values is only valid when the biological variabilities of reference population and target population are comparable to a large extent, e.g. the sex composition of the groups, the age of the persons in the groups, etc.

An usual finding is that the ranges of values for the laboratory determinations from healthy and nonhealthy populations and the population of patients with the disease to be studied, overlap to a greater or lesser extent. Decision limits must then be determined.

The information obtained by so-called longitudinal investigation is completely different $(1-4)$. In this type of study the parameters studied are determined in consecutive blood samples of a single individual during a longer period. Longitudinal appreciation has an advantage in comparison to the transverse approach. The patient is his own reference, so changes in parameter values, within the transverse reference range, or developing trends in consecutive values may be very indicative for underlying pathology. E.g. thyroxine serum levels in one patient changing within a certain period from $60 \mathrm{nmol} / 1$ to $128 \mathrm{nmol} / 1$ may indicate progressive hyperthyroidism, although both values are within the transverse reference range $(55-145 \mathrm{nmol} / \mathrm{l})$. However, the change from 60 $\mathrm{nmol} / \mathrm{l}$ to $128 \mathrm{nmol} / \mathrm{l}$ is not likely to be a physiological one and may confirm the diagnosis of hyperthyroidism.
Assessment of the meaning of longitudinal data requires a knowledge of intra-individual variability. A real problem is that sufficient data about intra-individual variation over a period of time are not available for most clinical chemical parameters. A reliable longitudinal appreciation of data is therefore not generally possible. The purpose of the present investigation is to assess the intra-individual variation of 28 clinical chemical parameters in a large population of healthy volunteers. Moreover, the so called critical differences will be calculated and considered. Often, the latter concern only the analytical bias. In the present study the intra-individual biological variability is also taken into account for the calculation of critical differences. Our study concerns the determination of the intra-individual variance in three different time spans:

$$
\begin{aligned}
& \text { - within-one-day } \\
& \text { - within-one-week (day-to-day) } \\
& \text { - within-six-months (month-to-month) }
\end{aligned}
$$

Extra attention has been paid to the constancy of analytical procedures and the pre-analytical treatment of the blood samples.

\section{Probands, Materials and Methods}

Individuals

The investigation of the within-one-day intra-individual variation has been started with a group of 62 apparently healthy volunteers ages 18-53 years. The group contained 23 males and 39 females from hospital laboratory personal (20 persons), medical staff (16) and students ( 26 persons).

Using a smallgroup $(n=16)$ an intermediate time span was investigated studying longitudinal intra-individual variations during a one week period.

Investigation of six months intra-individual variation was started with a group of 300 volunteers.

In the first two months 21 persons withdrew for various reasons (inconvenience, departure from the area, etc.). During the six month period another five persons were removed from the study on account of apparent disease. As a result the group of individuals participating in the study consisted of 274 volunteers ages 18 to 63 years old. Some were workers in various branches of chemical industry ( 84 persons), others were hospital laboratory personal (82 persons) and clerical personal (28 persons), male and female nurses (63 persons) and volunteers from a variety of other groups ( 17 persons). The group was subdivided in 148 males and 126 females including 72 male smokers, 54 female smokers and 61 females taking oral contraceptives.

Body weight, height and age of all individuals were registered. No gross restrictions were imposed on diet or activity during the study. The nature and purpose of the study were explained before-hand to all individuals, and its design was approved by the Ethical Committee.

All individuals were judged to be healthy at the beginning of the study by medical interview; no person suffering from chronic or recurrent illness was admitted. 
During the studies no serious illness or injury was observed apart from haematoma after venipuncture. No drugs, apart from oral contraceptives, were involved.

\section{Scheme of venipuncture}

For the within-one-day period, all blood specimens from one individual were taken at fixed times i.e. 8.30 and $11.00 \mathrm{a} . \mathrm{m}$. and 2.00 and $4.30 \mathrm{p} . \mathrm{m}$. in the course of one day. These times were chosen because in normal practice about $95 \%$ of blood samples for analysis are drawn within these hours.

For the day-to-day variation during six days 16 volunteers were daily subjected to venipuncture. For the month-to-month period 274 volunteers were subjected to venipuncture monthly over a period of six months. For each volunteer the venipuncture was carried out at the same time of the day.

\section{Specimens}

The individuals had a 10 to 15 minutes rest in a sitting position before venipuncture. While the subject was in a comfortable sitting posture blood was collected in vacuum blood collection tubes (Terumo ${ }^{\circledR}$ ). Brief tourniquet pressure was released immediately before venipuncture. The serum samples of all individuals were frozen at $-78^{\circ} \mathrm{C}$ until the day of analysis, when all specimens of one individual were thawed at room temperature, mixed thoroughly and analysed in the same run.

\section{Analytical procedures}

The automated analyses used were the same as used in daily routine for analysis for patient specimens.

\section{Variance components}

In general three variance components can be distinguished, a biological, an analytical and an "other one" (tab. 1) (5). For the present investigation the "other" component can be neglected: The main part of the "other" component is usually specimen collection; in the present study this was minimized by standardization of collection by using a vacuum collecting system. For each individual total individual variances $\left(\mathrm{s}_{\mathrm{T}}^{2}\right)$ can be calculated from the observations. Assuming the analytical component to be known, the biological one can be computed from:

$s_{\mathrm{B}}^{2}=\mathrm{s}_{\mathrm{T}}^{2}-\mathrm{s}_{\mathrm{A}}^{2}$

In this study we only consider the intra-individual variation (no inter-individual variance). Moreover all samples from one individual were analysed in the same run (no inter-run variance). According to the terminology of table $1, s_{B}=s_{P}$ and $s_{A}=s_{S}$, the reported results are mainly given in coefficients of variation (percentages). For instance $C_{V_{B}}=s_{B} / \bar{x} \cdot 100 \%$ whereas the mean $\bar{x}$ is based on the observations of one individual.

To characterize the variability of $\mathrm{CV}_{\mathrm{p}}$ for each parameter, three characteristics of the histogram of $62,16,274 \mathrm{CV}_{\mathrm{p}}$ values will be reported in the tables:

- the percentage of individuals with $\mathrm{CV}_{\mathrm{T}}>\mathrm{CV}_{\mathbf{S}}$ (denoted by $\left.\mathbf{n}_{\text {var. }}\right)$

- the median value, denoted by $\mathrm{CV}_{\mathrm{p} s 0}$

- the ninety percentile value, denoted by $\mathrm{CV}_{\mathrm{p} 90}$

\section{Critical differences}

The critical difference $d_{K}$ has been developed as a tool to follow the course of one laboratory parameter in one individual in consecutive measurements. The critical difference is dependent on the total variance $\mathrm{s}_{\mathrm{T}}^{2}$ for the one individual concerned. Because in
Tab. 1. Symbols for the variance components used in this study.

$\mathrm{s}_{\mathrm{T}}^{2}=$ total variance of one individual from a reference population.

$$
\begin{aligned}
& \mathrm{s}_{\mathrm{T}}^{2}=\mathrm{s}_{\mathrm{B}}^{2}+\mathrm{s}_{\mathrm{A}}^{2}+\mathrm{s}_{\mathrm{O}}^{2} \\
& \mathrm{~s}_{\mathrm{B}}^{2}=\text { biological variance } \\
& \mathrm{s}_{\mathrm{B}}^{2}=\mathrm{s}_{\mathrm{P}}^{2}+\mathrm{s}_{\mathrm{I}}^{2} \\
& \quad \begin{array}{l}
\mathrm{s}_{\mathrm{P}}^{2}=\text { intra-individual variance } \\
\mathrm{s}_{\mathrm{I}}^{2}=\text { inter-individual variance } \\
\mathrm{s}_{\mathrm{I}}^{2}=\text { absent in this study }
\end{array}
\end{aligned}
$$

$\mathbf{s}_{\mathrm{A}}^{2}=$ analytical variance

$$
\begin{array}{ll}
s_{A}^{2}=s_{S}^{2}+s_{L}^{2} & s_{S}^{2}=\text { variance within the run } \\
s_{L}^{2}=\text { variance between runs } & s_{L}^{2}=\text { absent in this study }
\end{array}
$$

$s_{O}^{2}=$ "other" variance, e.g. specimen collection

Corresponding coefficient of variation (percentages) are denoted by $\mathrm{CV}_{\mathrm{T}}, \mathrm{CV}_{\mathrm{B}}$ and $\mathrm{CV}_{\mathrm{A}}$.

$\mathrm{d}_{\mathrm{K}}=$ critical difference

$d_{K}=2 \sqrt{2 s_{T}^{2}}=2 \sqrt{2\left(s_{\mathrm{P}}^{2}+s_{S}^{2}\right)}$

or

$d_{K}=2 \sqrt{2 C_{T}^{2}}=2 \sqrt{2\left(C V_{P}^{2}+C V_{S}^{2}\right)}$

our study the critical difference is predominantly dependent on the intra-individual variance $s_{\mathrm{p}}^{2}$ and the within-run variance $s_{\mathrm{S}}^{2}$, it can be written as:

$d_{K}=2 \sqrt{2 s_{T}^{2}}=2 \sqrt{2\left(s_{P}^{2}+s_{S}^{2}\right)} \quad$ (in units)

or

$d_{K}=2 \sqrt{2\left(C V_{p}^{2}+C V_{S}^{2}\right)}$ (in percentages)

When longitudinal investigations are performed in clinical laboratory practice, the analytical variance $s_{A}^{2}$ is composed of the intrarun variance $s_{S}^{2}$ and the inter-run variance $s_{L}^{2}$; the critical difference is then calculated as:

$d_{K}=2 \sqrt{2\left(s_{P}^{2}+s_{A}^{2}\right)}$ (in units)

or

$d_{K}=2 \sqrt{2\left(C V_{p}^{2}+C V_{A}^{2}\right)}$ (in percentages)

\section{Statistical methods}

Each parameter in this study was investigated with the Friedman rank test (6) to determine whether a systematic pattern could be found. Such a pattern could be either an upward or a downward trend or a systematic low or high value at one particular point.

Several two group comparisons (like male versus female, smokers/non smokers) were performed using the Mann-Whitney test (7). Correlations were studied using the Spearman rank correlation test (7). 


\section{Results}

Evaluation of serial changes in a patient laboratory results requires an appreciation of the changes occurring in the healthy individual as a result of analytical variation and normal physiological fluctuations. More than 28 years ago $R$. J. Williams (8) introduced the concept of biochemical individuality and demonstrated the uniqueness of each individual in many physiological and biological respects.

\section{Analytical variation}

The analytical within-run variations $\left(\mathrm{CV}_{s}\right)$ are presented in terms of coefficients of variation (\%) in table 2 . With the exception of the creatine kinase $\mathrm{MB}$ $(4.3 \%)$, iron $(3.8 \%)$, ferritin $(10.0 \%)$, thyroxine $(6.0 \%)$ and triiodothyronine $(5.7 \%)$, the CV was always less than $2.9 \%$. Effects of long term storage of frozen specimens during 6 months at $-78^{\circ} \mathrm{C}$ were investigated by analysing a number of samples directly after the blood was taken and freezing parts of these specimens. The frozen samples were analysed after consecutive periods of storage at $-78^{\circ} \mathrm{C}$ (from one month up to six months). The total coefficient of variation calculated from the results of seven samples from the same specimens with increasing storage time, never exceeded the analytical coefficient of variation. Consequently, no significant influence of storage at $-78^{\circ} \mathrm{C}$ was found.

\section{Within-one-day variation}

The Friedman rank test (6) was applied to the data in order to investigate whether a systematic pattern existed in the consecutive parameter values during one day. No such patterns were observed, except slight trends for creatine kinase and aspartate aminotransferase (increase during the day) and serum bilirubin concentration (decrease during the day).

In blood samples taken at different times of one day, intra-individual variations were calculated. Two situations can occur: either $\mathrm{CV}_{\mathrm{T}}>\mathrm{CV}_{\mathrm{S}}$ in which case $C V_{\mathrm{P}}$ is found positive or $\mathrm{CV}_{\mathrm{T}} \leqslant \mathrm{CV}_{\mathrm{s}}$ in which case $\mathrm{CV}_{\mathrm{p}}$ cannot be calculated and is set to zero.

The first situation was observed for the great majority of the individuals for most parameters. For 20 of the 28 parameters more than $85 \%$ of the participating individuals show a positive $\mathrm{CV}_{\mathrm{p}}$. The results are summarized in table 2.

The within-one-day intra-individual variations, $\mathrm{CV}_{\mathrm{p} 50}$ and $\mathrm{CV}_{\mathrm{p} 90}$ were almost all different from zero for the serum constituents except for the $\mathrm{CV}_{\mathrm{p} 50}$ of
Tab. 2. Intra-individual variation during one day $(n=62)$.

\begin{tabular}{lllllll}
\hline Analyte & $n_{\text {var }}$ & $C V V_{S}$ & CV P50 & $d_{K 50}$ & $C V_{P 90}$ & $d_{K 90}$ \\
& $(\%)$ & $(\%)$ & $(\%)$ & $(\%)$ & $(\%)$ & $(\%)$
\end{tabular}

\begin{tabular}{|c|c|c|c|c|c|c|}
\hline \multicolumn{7}{|l|}{ Enzymes } \\
\hline Creatine kinase & 96 & 1.7 & 8.3 & 24.0 & 18.5 & 52.5 \\
\hline $\begin{array}{l}\text { Creatine } \\
\text { kinase-MB }\end{array}$ & 95 & 4.3 & 13.5 & 40.1 & 25.1 & 72.0 \\
\hline $\begin{array}{l}\text { Alanine amino- } \\
\text { transferase }\end{array}$ & 86 & 0.9 & 5.3 & 15.2 & 10.3 & 29.2 \\
\hline $\begin{array}{l}\text { Aspartate amino- } \\
\text { transferase }\end{array}$ & 95 & 0.9 & 4.7 & 13.5 & 9.4 & 26.7 \\
\hline $\begin{array}{l}\text { Lactate } \\
\text { dehydrogenase }\end{array}$ & 89 & 2.1 & 5.0 & 15.3 & 9.7 & 28.1 \\
\hline $\begin{array}{l}\alpha \text {-Hydroxy- } \\
\text { butyrate } \\
\text { dehydrogenase }\end{array}$ & 79 & 2.8 & 4.3 & 14.5 & 10.0 & 29.4 \\
\hline $\begin{array}{c}\gamma \text {-Glutamyl- } \\
\text { transferase }\end{array}$ & 96 & 1.3 & 5.7 & 16.5 & 12.8 & 36.4 \\
\hline $\begin{array}{l}\text { Alkaline } \\
\text { phosphatase }\end{array}$ & 94 & 0.9 & 2.7 & 8.0 & 5.1 & 14.6 \\
\hline$\alpha$-Amylase & 100 & 1.2 & 4.4 & 12.9 & 9.4 & 26.8 \\
\hline \multicolumn{7}{|l|}{ Electrolytes } \\
\hline Sodiur & 73 & 0.6 & 0.6 & 2.4 & 1.4 & 4.3 \\
\hline Potassium & 100 & 1.0 & 4.6 & 13.3 & 7.8 & 22.2 \\
\hline Chloride & 86 & 1.0 & 1.1 & 4.2 & 2.4 & 7.4 \\
\hline Calcium & 79 & 0.8 & 1.8 & 5.6 & 3.6 & 10.4 \\
\hline Phosphate & 96 & 1.4 & 10.4 & 29.7 & 19.6 & 55.6 \\
\hline
\end{tabular}

Intermediary metabolites

$\begin{array}{lrrrrrr}\text { Bilirubin } & 100 & 1.6 & 13.4 & 38.2 & 24.9 & 70.6 \\ \text { Glucose } & 100 & 1.5 & 13.3 & 37.9 & 25.8 & 73.1 \\ \text { Cholesterol } & 87 & 1.8 & 2.8 & 9.4 & 6.4 & 18.8 \\ \text { Triglycerides } & 100 & 2.8 & 14.3 & 41.2 & 33.9 & 96.2 \\ \text { Total protein } & 92 & 1.3 & 2.3 & 7.5 & 4.7 & 13.8 \\ \text { Albumin } & 81 & 1.8 & 2.4 & 8.5 & 5.0 & 15.0 \\ \text { Urea } & 95 & 1.8 & 4.8 & 14.5 & 9.7 & 27.9 \\ \text { Creatinine } & 94 & 1.6 & 3.4 & 10.6 & 6.8 & 19.8 \\ \text { Uric Acid } & 94 & 1.0 & 5.4 & 15.5 & 9.8 & 27.9\end{array}$

Iron status

$\begin{array}{lrrrrrr}\text { Iron } & 89 & 3.8 & 9.4 & 28.7 & 22.3 & 64.0 \\ \text { Transferrin } & 84 & 1.9 & 3.0 & 10.0 & 5.7 & 17.0\end{array}$

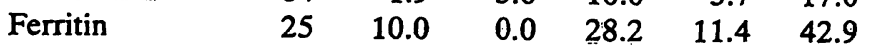

Thyroid hormones

$\begin{array}{lllllrr}\text { Thyroxine }\left(\mathrm{T}_{4}\right) & 30 & 6.0 & 0.0 & 17.0 & 6.0 & 24.0 \\ \text { Triiodo- } & 51 & 5.7 & 0.4 & 16.1 & 10.4 & 33.5\end{array}$
thyronine $\left(\mathrm{T}_{3}\right)$

$\mathrm{n}_{\mathrm{var}}=$ percentage of individuals with $\mathrm{CV}_{\mathbf{T}}>\mathrm{CV}_{\mathrm{S}}$

$\mathrm{CV}_{\mathrm{P50}}=$ median intra-individual coefficient of variation $\mathrm{CV}_{\mathrm{P} 90}=90$ percentile of intra-individual coefficient of vaariation

ferritin and thyroxine. As shown in table 2 the intraindividual variations varied from $0.0-14.3 \%$ $\left(\mathrm{CV}_{\mathrm{p} 50}\right)$ and from 1.4-33.9\% $\left(\mathrm{CV}_{\mathrm{p} 90}\right)$. The critical differencès varied from $2.4-41.2 \%\left(\mathrm{~d}_{\mathrm{K} 50}\right)$ and from $4.3-96.2 \%\left(d_{K 90}\right)$. 
The Mann-Whitney test (7) was applied in order to reveal those parameters showing differences in biological variations $\left(C_{\mathrm{p}}\right)$ and critical differences $\left(d_{K}\right)$ between the 50 percentile values and the 90 percentile values for the male/female groups, the smokers/ non smokers groups and the female groups using/not using oral contraceptives.

The only significant statistical differences for serum transferrin and triglycerides were found between the male versus the female groups. Between male smokers and non smokers significant statistical differences were found for potassium, creatinine and ferritin. Between female smokers and non smokers a significant statistical difference was found for calcium. Between females with and without oral contraceptives such differences were seen for aspartate aminotransferase, sodium and thyroxine $\left(\mathrm{T}_{4}\right)$. Although the differences are significant from a statistical point of view, they seem to be of no importance in clinical use.

Examination of scatter-diagrams and correlation coefficients revealed no correlations between intraindividual variation and age, height, body weight and levels of corresponding laboratory parameters. All but the phosphate and glucose variations of the within-one-day intra-individual variations are below or equal to the month-to-month intra-individual variations (tab. 2, 5). It can thus be concluded that the majority of the within-one-day intra-individual variations of clinical chemical parameters are smaller than or similar to the month-to-month intra-individual variations.

In table 3 are summarized the critical differences based on $\mathrm{s}_{\mathrm{L}}$ for both males and females, expressed in SI units.

The use of $d_{K 50}$ or $d_{K 90}$ is arbitrary. However, for clinical decisions $d_{\mathrm{K} 90}$ is preferable for maximum specifity, whereas greater sensitivity is obtained using $\mathrm{d}_{\mathrm{K} 50}$.

\section{Day-to-day variation}

Following the progress or the course of a disease or the response to treatment, the clinician may primarily be interested in changes in the concentration of serum constituents occurring with an interval of two to three days or a week. Therefore, we decided to study the short term day-to-day variation of 16 healthy individuals, this time span being intermediate between hours (within-one-day) and months. In table 4 the day-to-day variations are given of seven chemical parameters. These have been chosen with regard to mineral metabolism (sodium, potassium), enzyme pattern (alanine aminotransferase) and
Tab. 3. Critical difference on one day based on $s_{L}$.

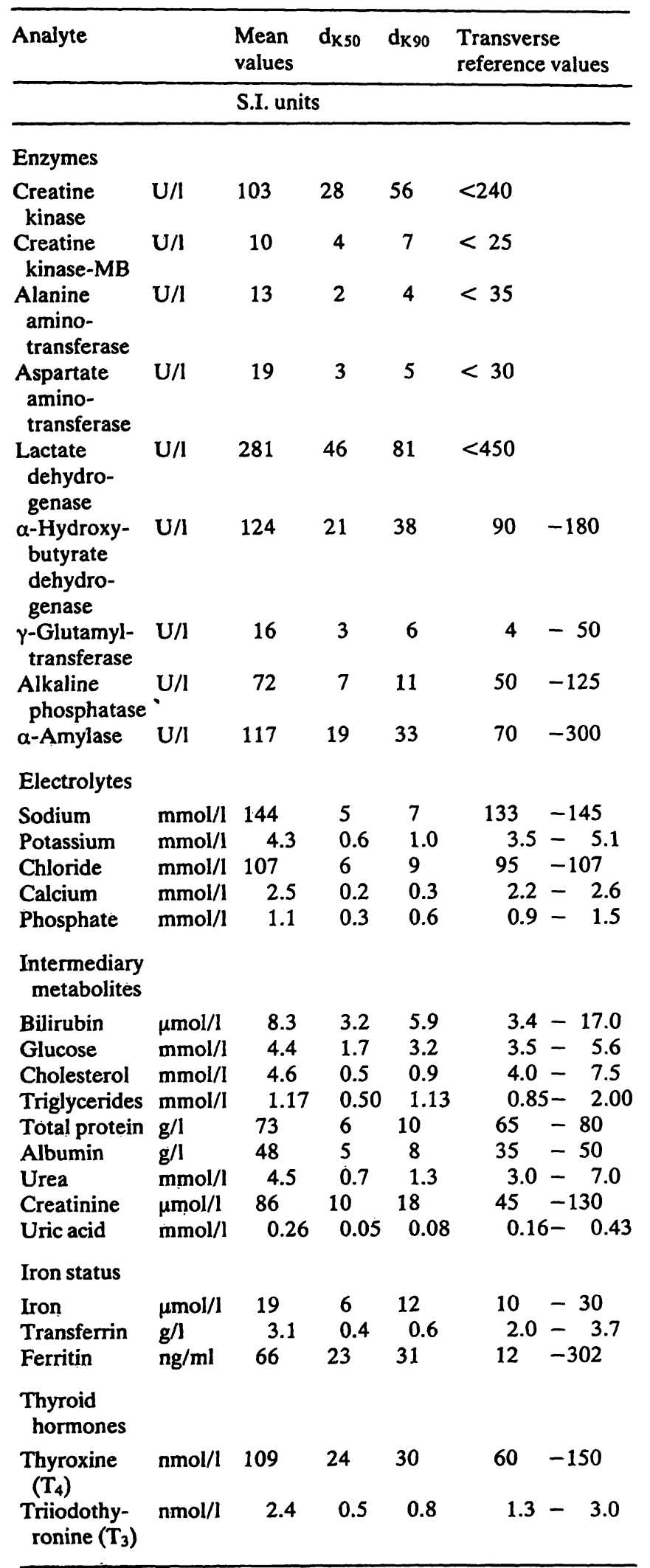

Mean values are taken over all time points and all individuals

intermediary metabolism (glucose, urea, creatinine and uric acid). All but the sodium variations of the day-to-day intra-individual variations are lower than the month-to-month intra-individual variations (vide infra). 
Tab. 4. Day to day intra-individual for a group of sixteen healthy individuals.

\begin{tabular}{|c|c|c|c|c|c|c|c|}
\hline & & Intra- & -indivic & dual va & ariation & & \\
\hline & & day to & o day & & & & month \\
\hline & & $\begin{array}{l}1 \text { vs } 2 \\
\text { (\%) }\end{array}$ & $\begin{array}{l}1 \text { vs } 3 \\
(\%)\end{array}$ & $\begin{array}{l}1 \text { vs } 4 \\
(\%)\end{array}$ & $\begin{array}{l}1 \text { vs } \\
\text { (\%) }\end{array}$ & $\begin{array}{l}1 \text { vs } 7 \\
(\%)\end{array}$ & $(\%)$ \\
\hline $\begin{array}{l}\text { Alanine ami- } \\
\text { notransferase }\end{array}$ & $\begin{array}{l}C V_{P 50} \\
C V_{P 90}\end{array}$ & $\begin{array}{l}13.5 \\
31.6\end{array}$ & $\begin{array}{r}9.2 \\
42.6\end{array}$ & $\begin{array}{l}10.6 \\
38.1\end{array}$ & $\begin{array}{l}13.3 \\
24.0\end{array}$ & $\begin{array}{l}18.6 \\
32.2\end{array}$ & $\begin{array}{l}30.0 \\
47.5\end{array}$ \\
\hline Sodium & $\begin{array}{l}C V_{P 50} \\
C V_{P 90}\end{array}$ & $\begin{array}{l}0.6 \\
0.8\end{array}$ & $\begin{array}{l}0.0 \\
0.8\end{array}$ & $\begin{array}{l}1.3 \\
1.9\end{array}$ & $\begin{array}{l}0.8 \\
1.3\end{array}$ & $\begin{array}{l}0.0 \\
0.8\end{array}$ & $\begin{array}{l}0.5 \\
1.3\end{array}$ \\
\hline Potassium & $\begin{array}{l}C V_{P 50} \\
C V_{P 90}\end{array}$ & $\begin{array}{l}2.6 \\
6.6\end{array}$ & $\begin{array}{l}1.3 \\
3.0\end{array}$ & $\begin{array}{l}3.1 \\
6.4\end{array}$ & $\begin{array}{l}1.4 \\
5.2\end{array}$ & $\begin{array}{l}2.2 \\
6.7\end{array}$ & $\begin{array}{l}4.5 \\
7.3\end{array}$ \\
\hline Glucose & $\begin{array}{l}C V_{P 50} \\
C V_{P 90}\end{array}$ & $\begin{array}{r}6.1 \\
17.2\end{array}$ & $\begin{array}{r}3.5 \\
11.7\end{array}$ & $\begin{array}{r}8.1 \\
16.8\end{array}$ & $\begin{array}{r}6.7 \\
11.3\end{array}$ & $\begin{array}{r}7.9 \\
16.8\end{array}$ & $\begin{array}{l}12.0 \\
20.8\end{array}$ \\
\hline Urea & $\begin{array}{l}C V_{P 50} \\
C V_{P 90}\end{array}$ & $\begin{array}{l}10.6 \\
18.8\end{array}$ & $\begin{array}{r}8.0 \\
22.7\end{array}$ & $\begin{array}{r}7.9 \\
18.9\end{array}$ & $\begin{array}{r}8.7 \\
18.9\end{array}$ & $\begin{array}{r}5.8 \\
18.7\end{array}$ & $\begin{array}{l}11.2 \\
18.9\end{array}$ \\
\hline Creatinine & $\begin{array}{l}C V_{P S 0} \\
C V_{P 90}\end{array}$ & $\begin{array}{l}2.8 \\
7.4\end{array}$ & $\begin{array}{l}2.7 \\
5.0\end{array}$ & $\begin{array}{l}2.5 \\
5.4\end{array}$ & $\begin{array}{l}2.7 \\
5.8\end{array}$ & $\begin{array}{l}2.1 \\
6.9\end{array}$ & $\begin{array}{r}5.7 \\
13.6\end{array}$ \\
\hline Uric acid & $\begin{array}{l}C V_{P 50} \\
C V_{P 90}\end{array}$ & $\begin{array}{r}4.4 \\
12.7\end{array}$ & $\begin{array}{r}5.9 \\
10.7\end{array}$ & $\begin{array}{l}4.2 \\
9.7\end{array}$ & $\begin{array}{r}7.7 \\
12.7\end{array}$ & $\begin{array}{r}6.7 \\
12.4\end{array}$ & $\begin{array}{r}8.0 \\
14.3\end{array}$ \\
\hline
\end{tabular}

\section{Month-to-month variation}

For the purpose of following the course of a chronic disease or for monitoring healthy individuals in a preventive medicine setting, we investigated monthto-month variations over a period of six months. Intra-individual variations were calculated from the analysis results of the blood samples taken every month at the same time of the day during a period of six months. Two situations can occur, either $\mathrm{CV}_{\mathrm{T}}>$ $C V_{S}$ in which case $C_{\mathrm{p}}$ is found positive or $C_{T} \leqslant$ $\mathrm{CV}_{\mathrm{s}}$ in which case $\mathrm{CV}_{\mathrm{p}}$ cannot be calculated and is set to zero.

The Friedman rank test (6) was applied to clinical chemical data from all individuals. No systematic low or high values or trends were found. The results for $\mathrm{CV}_{\mathrm{p}}$ are summarized in table 5.

Month-to-month intra-individual variations, $\mathrm{CV}_{\mathrm{p} 50}$ and $\mathrm{CV}_{\mathrm{p} 90}$ were all different from zero for all serum constituents (tab. 5). The critical differences varied from $2.2-89.1 \%\left(d_{\mathrm{K} 50}\right)$ and from $4.0-155.5 \%$ $\left(\mathrm{d}_{\mathrm{K} 90}\right)$.

Using the Mann-Whitney test (7) we looked for statistically significant differences in intra-individual variations between males and females. These have been found for alkaline phosphatase, calcium, glucose, cholesterol, total protein, albumin, urea, creatinine, uric acid, transferrin and ferritin. Between
Tab. 5. Intra-individual variation and the critical difference during six months $(n=274)$.

\begin{tabular}{|c|c|c|c|c|c|c|}
\hline Analyte & $\begin{array}{l}\mathrm{n}_{\mathrm{var}} \\
(\%)\end{array}$ & $\begin{array}{l}\mathrm{CV}_{\mathrm{s}} \\
(\%)\end{array}$ & $\begin{array}{l}C V_{P S 0} \\
(\%)\end{array}$ & $\begin{array}{l}d_{k s 0} \\
(\%)\end{array}$ & $\begin{array}{l}C_{P 90} \\
(\%)\end{array}$ & $\begin{array}{l}d_{K 90} \\
(\%)\end{array}$ \\
\hline Enzymes & & & & $: 1$ & & \\
\hline Creatine kinase & 100 & 1.7 & 22.8 & 64.7 & 45.1 & 127.6 \\
\hline $\begin{array}{l}\text { Creatine } \\
\text { kinase-MB }\end{array}$ & 100 & 4.3 & 31.2 & 89.1 & 54.8 & 155.5 \\
\hline $\begin{array}{l}\text { Alanine amino- } \\
\text { transferase }\end{array}$ & 100 & 0.9 & 30.0 & 84.9 & 47.5 & 134.4 \\
\hline $\begin{array}{l}\text { Aspartate amino- } \\
\text { transferase }\end{array}$ & 100 & 0.9 & 12.2 & 34.6 & 25.3 & 71.6 \\
\hline $\begin{array}{l}\text { Lactate } \\
\text { dehydrogenase }\end{array}$ & 100 & 2.1 & 10.3 & 29.7 & 17.7 & 50.4 \\
\hline $\begin{array}{l}\alpha \text {-Hydroxy- } \\
\text { butyrate } \\
\text { dehydrogenase }\end{array}$ & 99 & 2.8 & 8.8 & 26.1 & 16.5 & 47.3 \\
\hline $\begin{array}{l}\gamma \text {-Glutamyl- } \\
\text { transferase }\end{array}$ & 100 & 1.3 & 12.9 & 36.7 & 26.2 & 74.2 \\
\hline $\begin{array}{l}\text { Alkaline } \\
\text { phosphatase }\end{array}$ & 100 & 0.9 & 7.4 & 21.1 & 14.6 & 41.3 \\
\hline$\alpha$-Amylase & 100 & 1.2 & 8.7 & 24.8 & 21.8 & 61,8 \\
\hline \multicolumn{7}{|l|}{ Electrolytes } \\
\hline Sodium & 67 & 0.6 & 0.5 & 2.2 & 1.3 & 4.0 \\
\hline Potassium & 100 & 1.0 & 4.5 & 13.0 & 7.3 & 20.8 \\
\hline Chloride & 86 & 1.0 & 1.3 & 4.6 & 2.4 & 7.4 \\
\hline Calcium & 97 & 0.8 & 2.3 & 6.9 & 4.2 & 12.1 \\
\hline Phosphate & 100 & 1.4 & 9.5 & 27.2 & 14.2 & 40.4 \\
\hline \multicolumn{7}{|l|}{$\begin{array}{l}\text { Intermediary } \\
\text { metabolites }\end{array}$} \\
\hline Bilirubin & 100 & 1.6 & 18.7 & 53.1 & 28.6 & 81.0 \\
\hline Glucose & 100 & 1.5 & 12.0 & 34.2 & 20.8 & 59.0 \\
\hline Cholesterol & 100 & 1.8 & 6.5 & 19.1 & 12.3 & 35.2 \\
\hline Triglycerides & 100 & 2.8 & 21.6 & 61.6 & 34.2 & 97.1 \\
\hline Total protein & 96 & 1.3 & 2.6 & 8.2 & 5.1 & 14.9 \\
\hline Albumin & 94 & 1.8 & 3.2 & 10.4 & 6.2 & 18.3 \\
\hline Urea & 100 & 1.8 & 11.2 & 32.1 & 18.9 & 53.7 \\
\hline Creatinine & 99 & 1.6 & 5.7 & 16.7 & 13.6 & 38.7 \\
\hline Uric Acid & 100 & 1.0 & 8.0 & 22.8 & 14.3 & 40.5 \\
\hline \multicolumn{7}{|l|}{ Iron status } \\
\hline Iron & 100 & 3.8 & 19.8 & 57.0 & 33.4 & 95.1 \\
\hline Transferrin & 97 & 1.9 & 5.8 & 17.3 & 11.2 & 32.1 \\
\hline Ferritin & 82 & 10.0 & 12.8 & 45.9 & 37.8 & 110.6 \\
\hline \multicolumn{7}{|l|}{ Thyroid hormones } \\
\hline Thyroxine $\left(\mathrm{T}_{4}\right)$ & 72 & 6.0 & 4.8 & 21.7 & 13.4 & 41.5 \\
\hline $\begin{array}{l}\text { Triiodo- } \\
\text { thyronine }\left(T_{3}\right)\end{array}$ & 82 & 5.7 & 5.7 & 22.8 & 15.1 & 45.7 \\
\hline
\end{tabular}

male smokers and non smokers no differences were found. In the groups of female smokers and non smokers aspartate aminotransferase, lactate dehydrogenase, $\alpha$-hydroxybutyrate dehydroğenạse, alkaline phosphatase and albumin, however, showed such differences. Between females taking or not taking 'oral contraceptives, alkaline phosphatase, $\alpha$ amylase and thyroxine were significicantly different. 
The following differences are not only statistically, but probably also clinically relevant: in the male/female group alkaline phosphatase, creatinine and ferritin especially in the $C V_{p 90}$ and $d_{K 90}$. (tab. 6), in table 7 female smokers and non smokers lactate dehydrogenase, in the females taking/not taking oral contraceptives $\alpha$-amylase and thyroxine (tab. 8).

Tab. 6. Significant differences in the intra-individual variations during six months between males and females $(p<0.05)$.

\begin{tabular}{|c|c|c|c|c|c|c|c|}
\hline Analyte & Sex & $\mathbf{n}$ & $\begin{array}{l}\mathrm{CV}_{\mathbf{s}} \\
(\%)\end{array}$ & $\begin{array}{l}\text { CVPS0 } \\
(\%)\end{array}$ & $\begin{array}{l}d_{K 50} \\
(\%)\end{array}$ & $\begin{array}{l}C_{P 90} \\
(\%)\end{array}$ & $\begin{array}{l}d_{K 90} \\
(\%)\end{array}$ \\
\hline $\begin{array}{l}\text { Alkaline } \\
\text { phosphatase }\end{array}$ & $\begin{array}{l}\delta \\
q\end{array}$ & $\begin{array}{l}148 \\
126\end{array}$ & 0.9 & $\begin{array}{l}6.9 \\
8.2\end{array}$ & $\begin{array}{l}19.7 \\
23.3\end{array}$ & $\begin{array}{l}12.2 \\
17.8\end{array}$ & $\begin{array}{l}34.6 \\
50.4\end{array}$ \\
\hline Calcium & $\begin{array}{l}\delta \\
9\end{array}$ & $\begin{array}{l}148 \\
126\end{array}$ & 0.8 & $\begin{array}{l}2.2 \\
2.6\end{array}$ & $\begin{array}{l}6.6 \\
7.7\end{array}$ & $\begin{array}{l}4.0 \\
4.3\end{array}$ & $\begin{array}{l}11.5 \\
12.4\end{array}$ \\
\hline Glucose & $\begin{array}{l}\delta \\
9\end{array}$ & $\begin{array}{l}148 \\
126\end{array}$ & 1.5 & $\begin{array}{l}13.2 \\
10.4\end{array}$ & $\begin{array}{l}37.6 \\
29.7\end{array}$ & $\begin{array}{l}22.4 \\
20.1\end{array}$ & $\begin{array}{l}63.5 \\
57.0\end{array}$ \\
\hline Cholesterol & $\begin{array}{l}\delta \\
\wp\end{array}$ & $\begin{array}{l}148 \\
126\end{array}$ & 1.8 & $\begin{array}{l}6.0 \\
7.2\end{array}$ & $\begin{array}{l}17.7 \\
21.0\end{array}$ & $\begin{array}{l}10.8 \\
14.1\end{array}$ & $\begin{array}{l}31.0 \\
40.2\end{array}$ \\
\hline Total protein & $\begin{array}{l}\delta \\
\wp\end{array}$ & $\begin{array}{l}148 \\
126\end{array}$ & 1.3 & $\begin{array}{l}2.3 \\
3.2\end{array}$ & $\begin{array}{l}7.5 \\
9.8\end{array}$ & $\begin{array}{l}4.3 \\
5.7\end{array}$ & $\begin{array}{l}12.7 \\
16.5\end{array}$ \\
\hline Albumin & $\begin{array}{l}\delta \\
q\end{array}$ & $\begin{array}{l}148 \\
126\end{array}$ & 1.8 & $\begin{array}{l}2.7 \\
4.2\end{array}$ & $\begin{array}{r}9.2 \\
12.9\end{array}$ & $\begin{array}{l}5.1 \\
7.0\end{array}$ & $\begin{array}{l}15.3 \\
20.4\end{array}$ \\
\hline Urea & $\begin{array}{l}\delta \\
q\end{array}$ & $\begin{array}{l}148 \\
126\end{array}$ & 1.8 & $\begin{array}{r}9.7 \\
12.2\end{array}$ & $\begin{array}{l}27.9 \\
34.9\end{array}$ & $\begin{array}{l}17.8 \\
21.4\end{array}$ & $\begin{array}{l}50.6 \\
60.7\end{array}$ \\
\hline Creatinine & $\begin{array}{l}0 \\
q\end{array}$ & $\begin{array}{l}148 \\
126\end{array}$ & 1.6 & $\begin{array}{l}6.2 \\
5.3\end{array}$ & $\begin{array}{l}18.1 \\
15.7\end{array}$ & $\begin{array}{l}17.4 \\
11.7\end{array}$ & $\begin{array}{l}49.4 \\
33.4\end{array}$ \\
\hline Uric acid & $\begin{array}{l}\delta \\
q\end{array}$ & $\begin{array}{l}148 \\
126\end{array}$ & 1.0 & $\begin{array}{l}7.4 \\
9.0\end{array}$ & $\begin{array}{l}21.1 \\
25.6\end{array}$ & $\begin{array}{l}13.6 \\
15.5\end{array}$ & $\begin{array}{l}38.6 \\
43.9\end{array}$ \\
\hline Transferrin & $\begin{array}{l}\delta \\
9\end{array}$ & $\begin{array}{l}148 \\
126\end{array}$ & 1.9 & $\begin{array}{l}5.6 \\
6.4\end{array}$ & $\begin{array}{l}16.7 \\
18.9\end{array}$ & $\begin{array}{l}10.7 \\
12.3\end{array}$ & $\begin{array}{l}30.7 \\
35.2\end{array}$ \\
\hline Ferritin & $\begin{array}{l}\delta \\
\phi\end{array}$ & $\begin{array}{l}148 \\
126\end{array}$ & 10.0 & $\begin{array}{r}9.0 \\
17.1\end{array}$ & $\begin{array}{l}38.1 \\
56.0\end{array}$ & $\begin{array}{l}31.4 \\
43.9\end{array}$ & $\begin{array}{r}93.2 \\
127.3\end{array}$ \\
\hline
\end{tabular}

$\mathrm{n}=$ number of persons

Tab. 7. Significant differences in the intra-individual variations during six months between female smokers/non-smokers $(\mathrm{p}<0.05)$.

\begin{tabular}{|c|c|c|c|c|c|c|c|}
\hline \multirow[t]{2}{*}{ Analyte } & & \multirow[t]{2}{*}{$\mathbf{n}$} & \multicolumn{3}{|c|}{$\mathrm{CV}_{\mathrm{S}} \mathrm{CV}_{\mathrm{P} 50} \mathrm{~d}_{\mathrm{K} 50}$} & \multicolumn{2}{|c|}{$\mathrm{CV}_{\mathrm{P} 90} \mathrm{~d}_{\mathrm{K} 90}$} \\
\hline & & & $(\%)$ & $(\%)$ & $(\%)$ & $(\%)$ & $(\%)$ \\
\hline $\begin{array}{l}\text { Aspartate } \\
\text { amino- } \\
\text { transferase }\end{array}$ & $\begin{array}{l}\text { Smokers } \\
\text { Non-smokers }\end{array}$ & $\begin{array}{l}54 \\
72\end{array}$ & 0.9 & $\begin{array}{l}13.6 \\
10.3\end{array}$ & $\begin{array}{l}38.6 \\
29.2\end{array}$ & $\begin{array}{l}26.7 \\
21.5\end{array}$ & $\begin{array}{l}75.6 \\
60.9\end{array}$ \\
\hline $\begin{array}{l}\text { Lactate de- } \\
\text { hydrogenase }\end{array}$ & $\begin{array}{l}\text { Smokers } \\
\text { Non-smokers }\end{array}$ & $\begin{array}{l}54 \\
72\end{array}$ & 2.1 & $\begin{array}{r}11.9 \\
9.1\end{array}$ & $\begin{array}{l}34.2 \\
26.4\end{array}$ & $\begin{array}{l}20.0 \\
13.3\end{array}$ & $\begin{array}{l}56.9 \\
38.1\end{array}$ \\
\hline $\begin{array}{l}\alpha \text {-Hydroxy- } \\
\text { butyrate de- } \\
\text { hydrogenase }\end{array}$ & $\begin{array}{l}\text { Smokers } \\
\text { Non-smokers }\end{array}$ & $\begin{array}{l}54 \\
72\end{array}$ & 2.8 & $\begin{array}{l}9.9 \\
7.9\end{array}$ & $\begin{array}{l}29.1 \\
23.7\end{array}$ & $\begin{array}{l}17.6 \\
14.2\end{array}$ & $\begin{array}{l}50.4 \\
40.9\end{array}$ \\
\hline $\begin{array}{l}\text { Alkaline } \\
\text { phosphatase }\end{array}$ & $\begin{array}{l}\text { Smokers } \\
\text { Non-smokers }\end{array}$ & $\begin{array}{l}54 \\
72\end{array}$ & 0.9 & $\begin{array}{l}9.3 \\
7.5\end{array}$ & $\begin{array}{l}26.4 \\
21.4\end{array}$ & $\begin{array}{l}19.0 \\
16.5\end{array}$ & $\begin{array}{l}53.8 \\
46.7\end{array}$ \\
\hline Albumin & $\begin{array}{l}\text { Smokers } \\
\text { Non-smokers }\end{array}$ & $\begin{array}{l}54 \\
72\end{array}$ & 1.8 & $\begin{array}{l}3.8 \\
4.4\end{array}$ & $\begin{array}{l}11.9 \\
13.4\end{array}$ & $\begin{array}{l}7.0 \\
7.0\end{array}$ & $\begin{array}{l}20.4 \\
20.4\end{array}$ \\
\hline
\end{tabular}

Tab. 8. Significant differences in the intra-individual variations during six months between females using/not using oral contraceptives $(p<0.05)$.

\begin{tabular}{llllllll}
\hline & $\begin{array}{l}\text { Oral } \\
\text { con- } \\
\text { tra- } \\
\begin{array}{l}\text { cep- } \\
\text { tives }\end{array}\end{array}$ & & $(\%)$ & $(\%)$ & $(\%)$ & $(\%)$ & $(\%)$ \\
\hline Alkaline & + & 61 & 0.9 & 9.2 & 26.1 & 19.4 & 54.9 \\
phosphatase & - & 59 & & 7.6 & 21.6 & 16.8 & 47.6 \\
(1-Amylase & + & 61 & 1.2 & 9.6 & 27.4 & 28.5 & 80.7 \\
& - & 59 & & 8.6 & 24.6 & 16.1 & 45.7 \\
Thyroxine & + & 61 & 6.0 & 7.9 & 28.1 & 16.6 & 49.9 \\
$\left(\mathrm{~T}_{4}\right)$ & - & 59 & & 4.3 & 20.9 & 10.2 & 33.5 \\
\hline
\end{tabular}

Examining scatter diagrams and correlation coefficients we found no correlations between intra-individual variation and age, height, body weight and levels of corresponding laboratory parameters. In table 9 are summarized the critical differences $\left(d_{K 50}\right.$ and $d_{K 90}$ ) based on $s_{L}$ for both males and females expressed in absolute values (SI units).

\section{Discussion}

From a study of the literature on the (intra-individual) variability of laboratory data, it soon appeared that valid comparison with our data was very difficult. Many published investigations were concerned with groups of persons which were too small for solid statistical evaluation of intra-individual variation. Moreover, only a few of them paid sufficient attention to the pre-analytical conditions (such as blood taking equipment, "other" factors) and to the analytical procedure.

Investigators such as Steigterhem et al. (10) have studied the analytical intra-individual and inter-individual components of variance in a group of only 10 volunteers for 34 assays encompassing 22 different constituents. Replicate blood specimens were obtained four times weekly over a 4 week period. Nine constituents were measured with more than one instrument. In those studied analytical variances of more than $30 \%$ of total variance have been reported. The use of different analysers can be considered to be the main cause of the different (sometimes large) analytical variances $\mathrm{s}_{\mathrm{A}}^{2}$. This is in contrast with our study where all analyses were performed in such a way that $s_{A}^{2}$ is kept as low as possible. 
Tab. 9. The critical differences observed during six months for males and females based on $\mathrm{s}_{\mathrm{L}}$.

\begin{tabular}{|c|c|c|c|c|c|c|}
\hline \multirow[t]{2}{*}{ Analyte } & & \multirow{2}{*}{\multicolumn{2}{|c|}{$\begin{array}{l}\begin{array}{l}\text { Mean } \\
\text { values }\end{array} \mathrm{d}_{\mathrm{K} s 0} \\
\text { S.I. units }\end{array}$}} & \multirow[t]{2}{*}{$d_{K 90}$} & \multicolumn{2}{|c|}{$\begin{array}{l}\text { Transverse } \\
\text { reference values }\end{array}$} \\
\hline & & & & & & \\
\hline \multicolumn{7}{|l|}{ Enzymes } \\
\hline $\begin{array}{l}\text { Creatine } \\
\text { kinase }\end{array}$ & $\mathrm{U} / \mathrm{l}$ & 98 & 63 & 125 & $<240$ & \\
\hline $\begin{array}{l}\text { Creatine } \\
\text { kinase-MB }\end{array}$ & $\mathrm{U} / \mathrm{l}$ & 11 & 10 & 17 & $<25$ & \\
\hline $\begin{array}{l}\text { Alanine } \\
\text { amino- } \\
\text { transferase }\end{array}$ & $\mathrm{U} / \mathrm{l}$ & 15 & 13 & 20 & $<35$ & \\
\hline $\begin{array}{l}\text { Aspartate } \\
\text { amino- } \\
\text { transferase }\end{array}$ & $\mathrm{U} / 1$ & 20 & 7 & 14 & $<30$ & \\
\hline $\begin{array}{l}\text { Lactate } \\
\text { dehydro- } \\
\text { genase }\end{array}$ & $\mathrm{U} / \mathrm{l}$ & 286 & 85 & 144 & $<450$ & \\
\hline $\begin{array}{l}\alpha \text {-Hydroxy- } \\
\text { butyrate } \\
\text { dehydro- } \\
\text { genase }\end{array}$ & $U / 1$ & 114 & 30 & 54 & 90 & -180 \\
\hline $\begin{array}{c}\gamma \text {-Glutamyl- } \\
\text { transferase }\end{array}$ & $\mathrm{U} / 1$ & 22 & 8 & 16 & 4 & -50 \\
\hline $\begin{array}{l}\text { Alkaline } \\
\text { phosphatase }\end{array}$ & $U / 1$ & 71 & 15 & 29 & 50 & -125 \\
\hline$\alpha$-Amylase & $\mathrm{U} / 1$ & 122 & 30 & 75 & 70 & -300 \\
\hline \multicolumn{7}{|l|}{ Electrolytes } \\
\hline $\begin{array}{l}\text { Sodium } \\
\text { Potassium } \\
\text { Chloride } \\
\text { Calcium } \\
\text { Phosphate }\end{array}$ & $\begin{array}{l}\mathrm{mmol} / \mathrm{l} \\
\mathrm{mmol} / \mathrm{l} \\
\mathrm{mmol} / \mathrm{l} \\
\mathrm{mmol} / \mathrm{l} \\
\mathrm{mmol} / \mathrm{l}\end{array}$ & $\begin{array}{c}142 \\
4.4 \\
103 \\
2.4 \\
1.1\end{array}$ & $\begin{array}{l}3 \\
0.6 \\
5 \\
0.2 \\
0.3\end{array}$ & $\begin{array}{l}6 \\
0.9 \\
8 \\
0.3 \\
0.4\end{array}$ & $\begin{array}{c}133 \\
3.5 \\
95 \\
2.2 \\
0.9\end{array}$ & $\begin{array}{l}-145 \\
-\quad 5.1 \\
-107 \\
-\quad 2.6 \\
-\quad 1.5\end{array}$ \\
\hline \multicolumn{7}{|l|}{$\begin{array}{r}\text { Intermediary } \\
\text { metabolites }\end{array}$} \\
\hline $\begin{array}{l}\text { Bilirubin } \\
\text { Glucose } \\
\text { Cholesterol } \\
\text { Triglycerides } \\
\text { Total protein } \\
\text { Albumin } \\
\text { Urea } \\
\text { Creatinine } \\
\text { Uric acid }\end{array}$ & $\begin{array}{l}\mu \mathrm{mol} / \mathrm{l} \\
\mathrm{mmol} / \mathrm{l} \\
\mathrm{mmol} / \mathrm{l} \\
\mathrm{mmol} / \mathrm{l} \\
\mathrm{g} / \mathrm{l} \\
\mathrm{g} / \mathrm{l} \\
\mathrm{mmol} / \mathrm{l} \\
\mu \mathrm{mol} / \mathrm{l} \\
\mathrm{mmol} / \mathrm{l}\end{array}$ & $\begin{array}{c}8.1 \\
4.4 \\
5.4 \\
1.60 \\
72 \\
43 \\
4.9 \\
85 \\
0.27\end{array}$ & $\begin{array}{l}4.3 \\
1.5 \\
1.0 \\
0.99 \\
6 \\
4 \\
1.6 \\
14 \\
0.06\end{array}$ & $\begin{array}{c}6.6 \\
2.6 \\
1.9 \\
1.55 \\
11 \\
8 \\
2.6 \\
33 \\
0.11\end{array}$ & $\begin{array}{c}3.4 \\
3.5 \\
4.0 \\
0.85 \\
65 \\
35 \\
3.0 \\
45 \\
0.16\end{array}$ & $\begin{array}{l}-17.0 \\
-\quad 5.6 \\
-\quad 7.5 \\
-\quad 2.00 \\
-80 \\
-50 \\
-\quad 7.0 \\
-130 \\
5-\quad 0.43\end{array}$ \\
\hline \multicolumn{7}{|l|}{ Iron status } \\
\hline $\begin{array}{l}\text { Iron } \\
\text { Transferrin } \\
\text { Ferritin }\end{array}$ & $\begin{array}{l}\mu \mathrm{mol} / \mathrm{l} \\
\mathrm{g} / \mathrm{l} \\
\mathrm{ng} / \mathrm{ml}\end{array}$ & $\begin{array}{l}19 \\
3.2 \\
74\end{array}$ & $\begin{array}{c}11 \\
0.6 \\
34\end{array}$ & $\begin{array}{l}18 \\
1.0 \\
82\end{array}$ & $\begin{array}{c}10 \\
2.0 \\
12\end{array}$ & $\begin{array}{l}-30 \\
-\quad 3.7 \\
-302\end{array}$ \\
\hline \multicolumn{7}{|l|}{$\begin{array}{l}\text { Thyroid } \\
\text { hormones }\end{array}$} \\
\hline $\begin{array}{l}\text { Thyroxine } \\
\left(T_{4}\right)\end{array}$ & $\mathrm{nmol} / \mathrm{l}$ & 109 & 24 & 45 & 60 & -150 \\
\hline $\begin{array}{l}\text { Triiodothy- } \\
\text { ronine }\left(\mathrm{T}_{3}\right)\end{array}$ & nmol/1 & 2.3 & 0.5 & 1.1 & 1.3 & -3.0 \\
\hline
\end{tabular}

Mean values are taken over all months and all individuals

Harris et al. (11) applied standard statistical analysis of variance on data from weekly determinations of 15 blood constituents in each of 68 normal subjects, over a 3 months period. The purpose was to isolate and estimate the biological components of the observed variation. The most critical problem, i.e. separating variations from long-term analytical deviations in each individual's data record, were resolved with the aid of concurrent analysis of an assayed control serum. They stated that comparison of isolated personal variations with inter-individual variations indicate that many common blood tests could contribute to an individually distinctive blood "profile" if substantial improvements could be made in analytical precision. This is in accordance with our opinion. However, the number of parameters and participants in their study was smaller than in our study and their analytical variances seemed to be too large.

Young et al. (12) sampled blood, under controlled conditions, from 9 healthy subjects weekly for 10 weeks. Eighteen serum constituents were measured in duplicate in each sample in a single analytical run. In this way the analytical variation was minimised. Considerable variations in mean values and standard deviations of results were observed among the subjects. Compared with a previous study (11) from their laboratory, significantly different estimates of personal variation were noted for a number of constituents. The group studied showed as great a diversity in the mean concentrations of most constituents as was seen earlier in a larger, more heterogeneous group of normal individuals. The authors concluded that certain blood parameters depend more on personal characteristics than on broad demographic factors. It can be doubted whether their conclusions have general validity becausę only 9 persons participated in their study.

Winkel et al. (13) evaluated the variations in some serum constituents in a group of 11 healthy young men for two selected time intervals: short term dayto-day changes over a six day period and hour-tohour changes over two six hour periods in different weeks. Analytical variations appeared to be of considerable influence on total variations. It must be remarked that the group size is too small to obtain generally valid data.

Pickup et al. (14) stressed the importance of highcapacity multi-channel analysers for the estimation of long-term variability in serum constituents. By frozen storage of specimens from 37 volunteers $(20$ males/17 females) with subsequent analysis in a single machine run, long-term analytical variation may be eliminated, thus sharpening the estimates of intra-individual variation. The usual population-based reference ranges were found to be either insensitive or irrelevant to the study of concentration changes over time in most healthy subjectis. 
Lommel \& Weyer (9) studied a large group of highly selected origin, i. e. male soldiers between 18 and 23 years of age. This of course eliminates several influences such as age, sex, etc. but diminishes the applicability of their results to general practice.

Williams et al. (15) studied a group of 1105 individuals. Analyses were performed in weekly blood samples over a 12 weeks period. The assumption was tested that a reference group of individuals, sub-divided by age and sex, would give a narrower range of variation than does a larger mixed population. Their results implied the need for individual rather than population-based reference ranges, even if the latter were from persons of similar age and the same sex. Although in their study factors influencing the $S_{p}$ were not been considered, their conclusions are in accordance with our results.

\section{Conclusions}

In general, the conclusions of the investigations reported by others have sometimes limited value and are not in accordance with our data (tab. 10). Due to the relatively small number of participants in most of the described studies no meaning could be attributed to differences within groups such as male/female, smokers/non smokers, age intervals, body weight, height and females taking/not taking oral contraceptives. In our work, greater importance can be attached to these differences especially in those parameters where the analytical imprecision is very small (19). It is not unexpected that in determinations with greater analytical imprecision the pre-analytical influences are less pronounced.

In agreement with other investigators $(16,17)$ we state that the current use of "reference values" should now be reconsidered. The main reason is that reference ranges for many parameters are often much larger than the range of physiological intra-individual variations. Intuitively physicians do estimate intra-individual changes in laboratory values far higher than the general "reference values".

It can be concluded that the use of general transverse reference ranges is only suitable when pathology is accompanied by gross deviations.
Tab. 10. Published intra-individual variations $\left(C V_{P}\right)$.

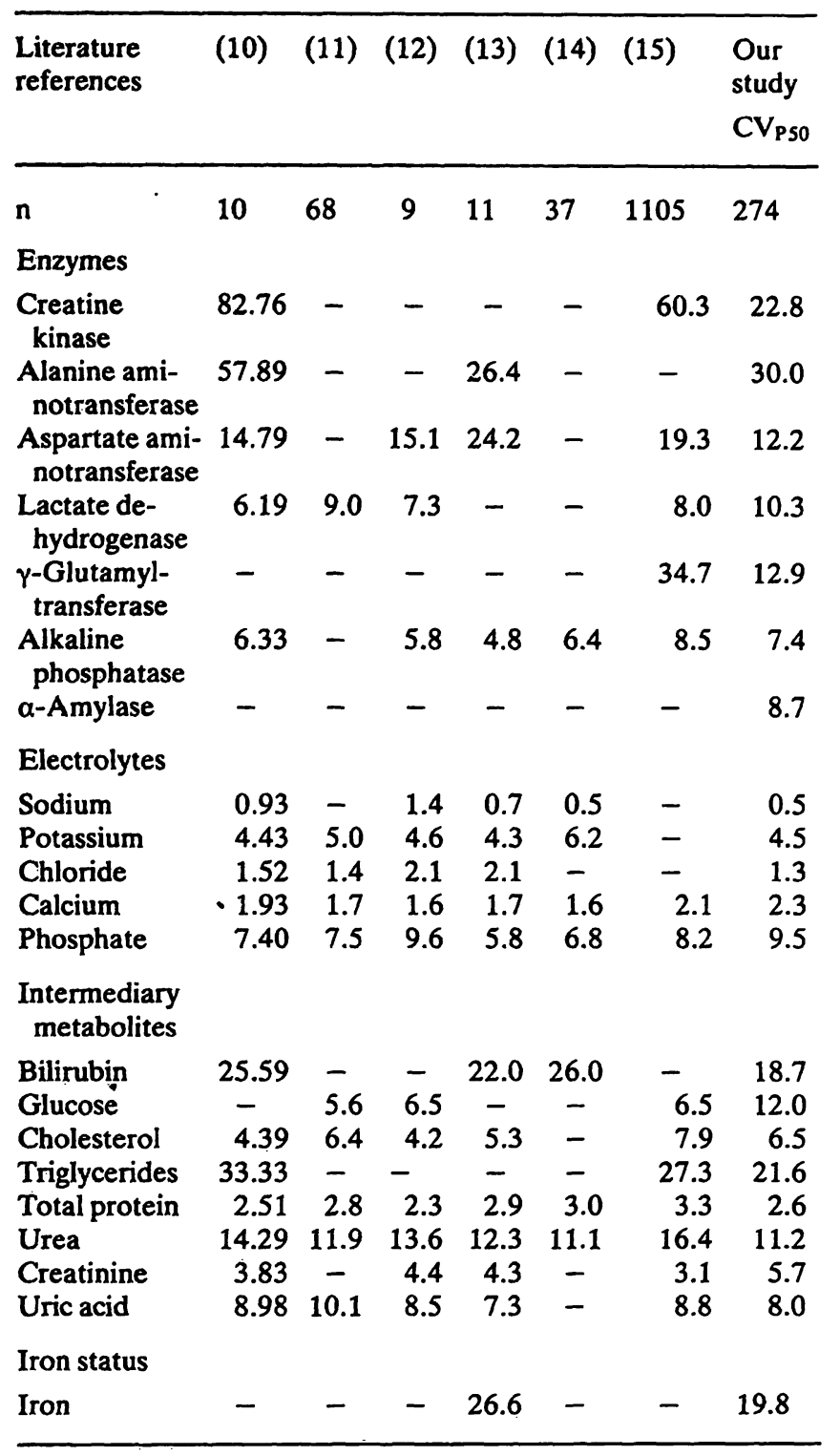

The use of intra-individual variations and calculated critical differences improve the value of laboratory data in diagnosis and treatment, because abnormal changes in parameter values in an individual within the transverse reference interval can be detected. We agree with others $(9,16)$ in regarding the necessity of considering the individual as his own reference and the use of critical difference values in longitudinal studies. It can be remarked that in screening for early detection of disease new decision limits must be determined which are different from the traditional transverse reference ranges (18).

\section{References}

1. Young, D. S. (1978) Clin. Chem. 24, 212-222.

2. Stamm, D. (1982) Clin. Chem. Clin. Biochem. 20, 817-824.

3. Statland, B. E. \& Winkel, P. (1977) CRC Crit. Rev. Clin. Lab. Sci. 10, 105-144.

4. Lommel, H. \& Weyer, M. G. (1982) Lab. Med. 6, 14-21.
5. Stamm, D. (1981) Control of Analytical Variation in the Production of Reference Values, In: Reference Values in Laboratory Medicine (Gräsbeck, R. \& Alström, T., eds.) New York, John Wiley \& Sons, pp. 109-126.

6. Friedman, M. (1937) J. Am. Statist. Assoc. 32, 675-701. 
7. Armitage. P. (1971) Statistical Methods in Medical Research. Oxford, Blackwell Sc. Publications.

8. Williams. R. J. (1956) Biochemical Individuality, New York, John Wiley \& Sons.

9. Lommel, H. \& Weyer, M. G. (1981) Long, I., Mainz, Verlag Kircheim \& Co.

10. Van Steigterhem, A. C., Robertson, E. A. \& Young, D. S. (1978) Clin. Chem. 24, 212-222.

11. Harris, E. K., Kanofsky, P., Shakarji, G. \& Cotlove, E. V. (1970) Clin. Chem. 16, 1022-1027.

12. Young, D. S., Harris, E. K. \& Cotlove, E. V. (1971) Clin. Chem. 17, 403-410.

13. Winkel, P., Statland, B. E. \& Bokelund, H. (1974) Clin. Chem. 20, 1520-1527.
14. Pickup, J. F., Harris, E. K., Kearns, M. \& Brown, S. S. (1977) Clin. Chem. 23, 842-850.

15. Williams, G. Z., Widdowson, G. M. \& Penton, J. (1978) Clin. Chem. 24, 313-320.

16. Keller, H. (1980) Einflüsse auf klinisch=chemische Meßgrößen. In: Validität klinisch chemischer Befunde (Long, $H$., Rick, W. \& Büttner, H., eds.) Berlin/Heidelberg/New York, Springer-Verlag, pp. 25-49. . 1

17. Feinstein, A. R. (1977) Cliniçal Biostatics. St. Louis, Mosby Comp.

18. Haeckel, R. (1979) Deutsches Ärzteblatt 39, 713.

19. Costongs, G. M. P. J., Janson, P. C. W. \& Brombacher, P. J. (1984) J. Clin. Chem. Clin. Biochem. 22, 613-622.

Dr. med. G. M. P. J. Costongs Hospital "De Goddelijke Voor-Zienigheid" Dept. of Clinical Chemistry

Walramstraat 23

NL-6131 BK Sittard 